\title{
PEMBERDAYAAN MASYARAKAT MELALUI PEMANFAATAN PRODUK KERUPUK BERBAHAN KULIT
}

\author{
Ahmad Muzanni1, Murni2, Majidah $3^{*}$ \\ 1Fakultas Keguruan dan IImu Pendidikan, Universitas Mataram \\ 2Fakultas Keguruan dan IImu Pendidikan, Universitas Mataram \\ ${ }_{3}$ Fakultas Hukum, Universitas Mataram \\ *Co-Author: MajidahFH98@gmail.com
}

\begin{abstract}
ABSTRAK. Desa Rumak merupakan salah satu desa yang terletak di Kecamtan Kediri, Kabupaten Lombok Barat. Desa ini terdiri dari 4 dusun yang Mayoritas penduduk Rumak pun banyak yang bekerja di kota mataram, dan sebagian masih bekerja di dalam desa mulai dari berkerja di pertokoan sampai masih ada sebagian kecil yang berkerja lapangan seperti petani di sawah. Masalah yang dihadapi desa ini yaitu pengembangan produk olahan dan ruang lingkup pemasaran yang relative sempit. Dari sekian banyak masalah yang ada, masalah pengembangan produk kerupuk kulit berbahan Kulit sapi menjadi topik utama yang sangat perlu untuk dikembangkan. Permasalahan pengembangan produk keripik Kulit ini dikarenakan kurangnya kemampuan masyarakat di Desa Rumak yaitu dalam mempromosikan dan memasarkan produk. Upaya untuk mengembangkan produk Kerupuk Kulit di desa Rumak, Kami akan membuat Varian Rasa Kerupuk Kulit sapi dan melatih mayarakat untuk dapat mepromosikan produknya secara lebih luas. Metode yang digunakan adalah merekrut masyarakat dari masing-masing dusun yang ada di Rumak sebagai peserta pelatihan pembuatan kerupuk Kulit berbahan Sapi, Pelatihan pengolahan kerupuk sapi, Pembaharuan kemasan dan varian rasa produk kerupuk kulit sapi , dan Promosi atau pemasaran produk olahan baik secara offline, online.
\end{abstract}

Kata Kunci: Rumak, kerupuk kulit sapi, varian rasa, pemasaran.

ABSTRACT. Rumak Village is one of the villages located in Kediri District, West Lombok. This village consists of 4 hamlets with the majority of the population of Rumak working in the city of Mataram, and most of them are still working in the village starting from those who work in the shops to the smaller ones who work in the fields like farmers in the fields. The problem related to this village is the relatively limited development of processed products and marketing. Of the many problems that exist, the problem of the development of leather products made from cow leather called "kerupuk Kulit Sapi" becomes the main topic that really needs to be developed. The problem of developing this product affects the ability of people in Rumak Village to support and market the product. Efforts to develop product's "kerupuk Kulit Sapi" in the village of Rumak, we will make a variant of "kerupuk Kulit Sapi"and train the community to be able to promote their products widely. The method used is to recruit people from each hamlet in Rumak as a participant in training in making "kerupuk Kulit Sapi", training in making "kerupuk Kulit Sapi", renewing packaging and flavor variants of "kerupuk Kulit Sapi", and Promotion or marketing of processed products both offline, online.

Keyword: Rumak, Kerupuk Kulit Sapi , flavor variants, marketing 


\section{PENDAHULUAN}

Kata produk berasal dari bahasa inggris product artinya "sesuatu yang diproduksi oleh tenaga kerja atau sejenisnya". Menurut Fandy Tjiptono (1999) mengatakan bahwa produk adalah segala sesuatu yang dtawarkan produsen untuk diperhatikan, diminta, dicai, digunakan atau dikonsumsi pasar ssebagai pemenuhan kebutuhan atau keinginan pasar yang bersangkutan.

Produk tediri dari beberapa jenis,yaitu produk konsumsi, dan produk industri. Produk konsumsi disebut juga dengan barang kebutuhan sehari-hari. Produk konsumsi merupakan barang yang umumnya dikonsumsi atau digunakan sendiri ataupun diberikan kepada orang lain dan pembelinya didasarkan atas kebiasaan dari konsumen itu sendiri. (H. Djaslim Saladi, 2003)

Salah satu produk konsumsi adalah produk kerupuk yang berbahan kulit sapi. Kerupuk kulit sapi merupakan makanan yan berasal dari bahan dasar kulit sapi yang masih muda (menghasilkan produk kulit sapi yang berkualitas).

Produktivitas pengolahan Kerupuk Kulit di desa Rumak di kata sangat rendah. selain dikarenakan masyarakat masih kebiasaan membuat kerupuk yang berbahan nasi dan tepung, kurangnya pengetahuan atau pemahaman masyarakat tentang bagaimana cara pengolahan kerupuk berbahan kulit sapi yang baik dan berkualitas. Selain itu, yang menjadi permasalahan di masyarakat yaitu terkait varian rasa, pemasaran dan promosi sebuah produk olahan baik produk kerupuk kulit sapi ataupun produk kerupuk yang sudah di produksi. Masyarakat di desa Rumak masih mempromosikan produk hanya sebatas "Door to Door" atau berkeliling setiap rumah.

Pelatihan pengolahan produk olahan berbahan kulit sapi bertujuan untuk selain memberikan edukasi atau pemahaman tentang bagaimana cara pengolahan limbah kulit sapi menjadi sebuah produk baik dan berkualitas tinggi dan memiliki kemasan dan bervarian rasa yang baru. Selain itu Pelatihan ini juga bertujuan memberikan pandangan atau pengetahuan masyarakat tentang cara mempromosikan dan memasarkan sebuah produk baik secara offline dan online.

\section{METODE PELAKSANAAN}

\section{Waktu dan Tempat}

Kegiatan dilakukan pada tanggal 26 Desember - 16 Januari di Desa Rumak Kecamatan Kediri Kabupaten Lombok Barat.

\section{Persiapan dan Pembekalan}

Persiapan yang kami adakan yakni kegiatan survey lapangan yang kami lakukan bertujuan untuk mengetahui potensi apa saja yang dimiliki oleh desa sasaran dan yang masih belum dikembangkan. Adapun kegiatan yang dilakukan selama survey adalah yang pertama melakukan tinjauan langsung (observasi), melakukan wawancara dengan pihak pemangku jabatan desa, berdiskusi dengan pengurus atau staff desa.Kedua penyususan program kerja utama yang telah disepakati kelompok kemudian disusun sesuai dengan format dari LPPM.Ketiga pengajuan proposal KKN Tematik ke LPPM dan presentasi proposal. 


\section{Pelaksanaan Program}

Tahap kedua yaitu pelaksanaan program, yang kami adakan yakni kegiatan: (1) Perekrut peserta pelatihan; (2) Pelatihan pengolahan; (3) Pembaharuan kemasan dan varian rasa; dan (4) Promosi atau pemasaran produk

\section{HASIL DAN PEMBAHASAN}

Peembuatan produk olahan kerupuk berbahan kulit sapi sekaligus pengemasan dan pemasaran. Kegiatan pemberdayaan masyarakat ini dimulai dengan melakukan persiapan meliputi survey lokasi. Hasil dari survei menunjukkan bahwa kendala yang dihadapi masyarakat Rumak antara lain 1) masyarakat masih kurang paham cara mengolah kerupuk kulit sapi. 2) kurangnya pengetahuan tentang pengemasan dan variain rasa. 3) kurangnya pengetahuan tentang cara pemasaran secara online. Selanjutnya adalah pelatihan

\section{Perekrut peserta pelatihan}

Perekrutan peserta pelatihan dilakukan mulai dengan cara membagi anggota kelompok berkeliling di setiap dusun untuk mensosialisasikan program utama sekaligus mengajak masyarakat unntuk mengikuti pelatihan

\section{Pelatihan pengolahan}

Pelatihan pembuatan kerupuk berbahan kulit sapi mulai dilakukan pada tanggal 3 Januari 2020 di desa Rumak tepatnya di Dusun Rumak Barat Selatan.

Pelatihan pembuatan kerupuk kulit yang dilakukan di Rumak Barat Selatan (RBS) dilakukan dari tahap yang pertama yaitu pembelian bahan kulit sapi pengorengan sampai dengan memberikan varian rasa dan pengemasan semua kegiatan ini dilakukan bersama dengan masyarakat yang mengikuti kegiatan pelatihan tersebut.

Pelatihan ini meliputi: a). pembelian bahan kulit sapi dari pemotong sapi atau rumah pemotongan hewan (RPH), b).Membersihkan Kulit sapi c).Proses perebusan Kulit Sapi d).Menghilangkan Bulu pada Kulit. e).Proses pengirisan kulit sapi yang sudah bersih f).Peroses pemberian bumbu. g). Peroses penjemuran h). Proses pemotongan stik kulit sapi. i).Pengaluman atau proses penggorengan setengah matang stik kulit sapi. j).Proses penggorengan kulit sapi.
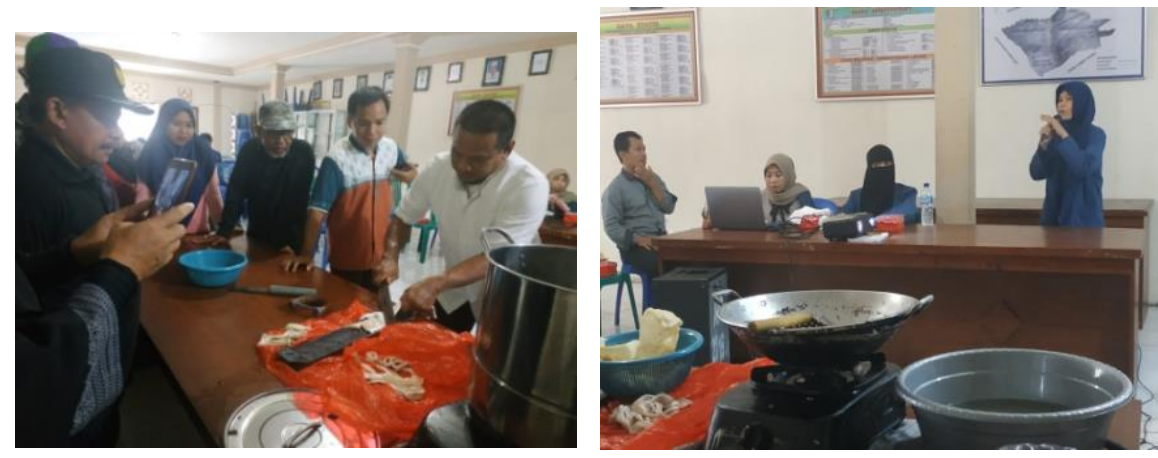

Gambar $1 . \quad$ Pelaksanaan Pelatihan pengolahan 


\section{Pembaharuan kemasan dan varian rasa}

Sebelum dilakukannya kegiatan pengemasan masyarakt diberikan edukasi tentang bagaimana pentingnya varian rasa dalam sebuah produk. Dalam hal ini produk olahan kerupuk kulit sapi. Selanjutnya Kegiatan pengemasan. Kegiatan pengemasan ini dilakukan dengan 2 tahap yang pertama memberikan edukasi tentang pengemasan tersebut, dan kedua melakukan pelatihan dalam pembaharuan pengemasan.

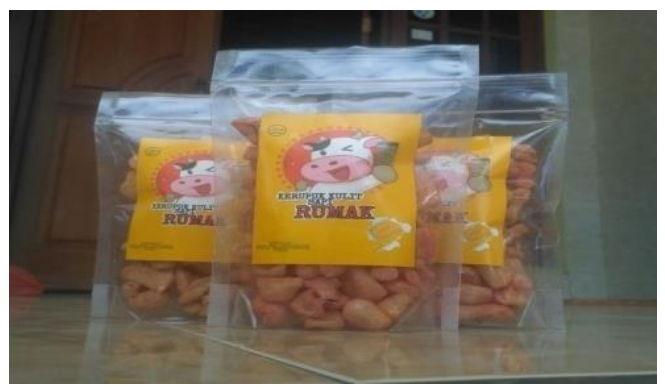

Gambar 2. Pembuatan kemasan dan pengemasan

\section{Promosi atau pemasaran produk}

Kegiatan promosi dan pemasaran dilakukan dengan memberikan edukasi ataupun pemahaman bagaimana cara memasarkan atau mempromosikan suatu produk suapaya produk tersebut bisa berkembang ataupun maju. Dalam hal ini kegiatan promosi dan pemasaran baik secar offline dan online. Sekaligus mencontohkan secara langsung bagaimana cara mempromosikan dan memasarkkan produk secar online.

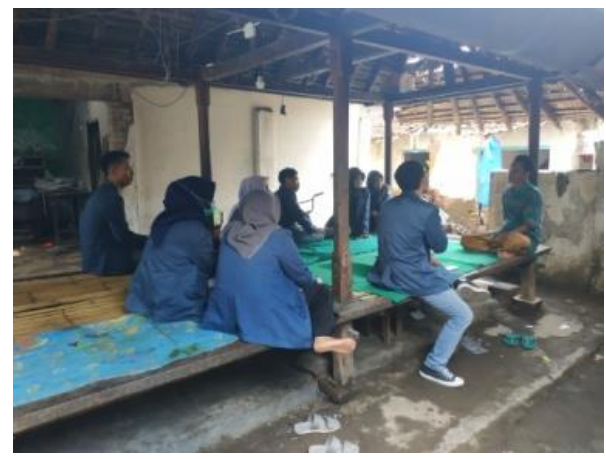

Gambar 3. Pelaksanaan edukasi tentang pemasaran atau mempromosikan suatu promosi

\section{KESIMPULAN}

Simpulan dari program pemberdayaan masyarakat tentang pengolahan produk kerupuk kulit adalah masyarakat Desa Rumak dapat mengolah limbah kulit sapi menjadi sebuah kerupuk kulit. Selain itu masyarakt juga lebih memiliki wawasan tentang bagaimana cara pengemasan, membrikkan varian rasa, dan pemasaran sebuah produk baik secar offline maupun online.

\section{REFERENSI}

Tjiptono, Fandy. 1999, Strategi Pemasaran, Edisi Kedua. Yogyakarta: Andi.

Saladin, Djaslim. 2003. Intisari Pemasaran dan Unsur-unsur Pemasaran, Cetakan Ketiga. Bandung : Linda Karya. 